\title{
An Art Phenomenon Under the State Control: Case Study on Shadow Puppet Performance
}

\author{
Sutiyono Sutiyono ${ }^{1}$ \\ ${ }^{1}$ Faculty of Languages and Arts, Yogyakarta State University, Yogyakarta, Indonesia \\ Correspondence: Sutiyono. Tel: 0274-5-8616-8381. E-mail: sutiyono@uny.ac.id
}

Received: November 23, 2018

Accepted: December 13, 2018

Online Published: January 30, 2019

doi:10.5539/ass.v15n2p172

URL: https://doi.org/10.5539/ass.v15n2p172

\begin{abstract}
This article aimed at revealing the ruling class and the group being ruled in the society. The concern on the ruling party is to create obedience and to eliminate resistance from the ruled group. In this case, Gramsci presented the theory of hegemony by taking control on intellectually and morally leadership that can be accepted through consciousness process. In line with the explanation of hegemony, it seems that the Indonesia government, in the era of New Order (Orde Baru) from 1966 till 1998, was a powerful state with the highest authority control and became a determining force against the socio-political dynamics in the society. During Nee Order period, the state was truly capable of leading and dominating the field of power in various fields of development and statehood. One way to build hegemony is through institutions that determine the cognitive structure in the society, one of them was through the art of puppet. Consequently, puppeter (dalang) as one of intellectual figures in the society was controlled in order to socialize Golkar Party, as the political instrument. It can be concluded that the New Order government has successfully hegemoned the art of puppet.
\end{abstract}

Keywords: art, shadow puppet, phenomenon, state, control

\section{Introduction}

To obtain public support, Soeharto used Golkar (Golongan Karya/Functional Group) Party for his electoral machine. Golkar always dominated the election compared to other political parties in 1971 till 1997 and the number of parliament mostly came from this party. It made Suharto had always been elected as the president of Indonesia and Golkar became the "state" party. Soeharto considered it necessary to use art instruments to gain the support for the party. One of them was through puppet performance to attract the public appeal. The puppeteer as a director of puppet show was believed as smart person in a very potential area to convey a political message to the public. As a result, the puppeteer were managed by the government as the campaigner to expand the public support and participation for Golkar.

Shadow puppet is made of buffalo leather which is embossed and colored according to its character. The show takes the story from the epics of Mahabharata and Ramayana. There are Rama, Laksmana, Sinta, Arjuna, Bima, Lord Vishnu, Brahma, Durga, Dewi Sri, Dewi Kunthi, Dewi Srikandhi, and so on. The shadow puppet show is a drama performance accompanied by gamelan (Javanese music). Wayang (puppet) comes from the word 'Hyang', which means the spirit, deity, or God. Meanwhile, the word "shadow" is from Javanese term because the audience can watch the performance behind the scenes or the shadow only.

The puppeteer plays the puppet and becomes the narrator for its dialogue. The music played by a group of gamelan musician (pengrawit) and songs form sindhen (female singers). The puppeteer plays the puppet behind the white scenes with the electric light or oil lamp (blencong) behind, so that the audience from the back side of the screen can see the shadow of the puppet through the screen. The shadow puppet include as an original Indonesian traditional art and it has been declared by UNESCO on November 7, 2003, as an amazing cultural work in the field of beautiful and precious heritage of narrative stories (Masterpiece of Oral and Intangible Heritage of Humanity).

The puppeteer is defined as one who has a special skill in playing shadow puppets. The skill is obtained hereditary from his father, without any formal learning. They follow and assist his father during the performance by bringing the equipment, setting the stage, arranging the puppet (nyimping), being a gamelam muscician, or sitting behind his father to prepare the puppets to be played. By following his father performance several times, 
from child till adolescence, the learning process occurs naturally, and mostly the puppeteer's son will be able to perform shadow puppet after grow up. Besides, there are also some puppeteers who studied at puppetry majors, either in senior high or university level, such as Indonesian Art Institute of Yogyakarta and Surakarta. Those univesities also produce a puppeteer who does not have descendant line of puppeteer, but only a few who posses strong intention to learn and, finally, can be puppeteer.

Some people argue that the word "dalang" derive from "dhahyang" which means a cure of various diseases. "Dalang" in "jarwo dhosok" interpreted as "ngudhal piwulang" (disclose knowledge), giving enlightenment to the audience. Thus, puppeter must have a very wide range of knowladge. Various fields of science must be learned to support the process of story building because the contents should adjust to the current development and the modern values. The puppeteer has aboundant or role where they act as a director, a playwright, a narrator, a character player, an accompanist, a singer, and a performer. It means puppeteer has multiple abilities and also as a manager or at least a leader in the shadow puppet performance.

The Golkar Party was founded in 1964 by the Army to counter the influence of the Indonesian Communist Party in the political life. In the 1971 election was followed by United Development Party/PPP, Indonesian Democratic Party/PDI), and Golkar Party. Golkar Party dominated the election in the New Order era, and Soeharto concurrently became president. The domination of Golkar party lasted in the following elections in 1977, 1982, 1987, 1992, and 1997. This incident could be possible, because the party system may have been heavily controlled and manipulated, Golkar, nevertheless, received various favours from the government to ensure the endurance of the New Order's rule, as a simple example monoloyalitas of civil servant.

After Suharto stepped down as president and the reformation era rolled out, Golkar Party for the first time participated in the elections without any special policy support as before. In 1999 the presidential election held by President Habibie, Golkar Party's fell to second place after the Indonesian Democratic Party.

The dissatisfaction with Megawati Soekarnoputri's government became one of the reasons for the majority to vote Golkar Party for the public legislative elections in the 2004, over other parties such as the Democratic Party, the National Awakening Party (PKB), and others. Golkar Party won the legislative election in 2004 with $24,480,757$ votes or $21.58 \%$ of the total valid votes. The victory was an achievement for the Golkar Party because in the 1999 Legislative Election, the Indonesian Democratic Party (PDI) dominated the result. In the 1999 election, Golkar Party was ranked second with $23,741,758$ votes or $22.44 \%$ of the valid votes. In brief, Golkar Party received the escalation of 738,999 votes, but the percentage reduced as much as $0.86 \%$.

Golkar Party is a state party because the government, from the local to the center, was handled by Golkar mambers. The Indonesian president was originally the chairman of Golkar Party, and, later, became the advisor of the party. Suharto was born in Kemusuk, Argomulyo, Sedayu, Bantul, Yogyakarta, 1921 and died in Jakarta in 2008. He was the second President of Indonesia for the period of 1967 to 1998. The western world often called Suharto as the Smiling General due to his smiling face. Before becoming president, Suharto was a military leader during the Japanese and Dutch occupation. Soeharto, then, took power from Sukarno, the Indonesian first president. Soeharto was officially elected president in 1967. He was re-elected by the People's Consultative Assembly in 1973, 1978, 1983, 1988, 1993, and 1998. In 1998, his regime ended after resigning after May 1998 chaos. Suharto served as president of Indonesia with the longest period. Thus, he can be called a successful man in leading Indonesia for 32 years.

It raise a question why Soeharto and his crony can maintain their leadership pattern and gain the support from the public for 32 years as well as the strategies they made. One of the strategies was empowering the puppeteer and puppet show as a political instrument to attract the public support for Golkar Party. The puppeteers served as the campaigners of Golkar.

The puppeteers who succeeded in playing role as the campaigners and contributing to Golkar winning, were rewarded by Suharto, such as the car and the hajj pilgrimage. With this incentive, Soeharto can dictate the puppeteers to perform based on the governments' policy and agenda. In performaning, shadow puppet is painted with a picture of the ideal life and state and also the state policy and the statehood. It seemed that the shadow puppet show became a tool of state hegemony to gain supporter as much as possible for Golkar Party.

Through the hegemony, Golkar Party intervened shadow puppet show in the form of the banyan tree-themed story and the golden yellow color represented the flag of Golkar Party, such as Pandawa Ringin, Ringin Kembar, Waringin Kencana, and Semar Mbangun Kencana Building. Soeharto's attempt to socialize Golkar through state intervention on shadow puppet show can be called as the state hegemnoni on arts.

Guy (1997) in his report on "Peking Opera and Politics in Post-1949 Taiwan" revealed that state-controlled art, 
as happened in the performing arts of "Peking Opera" in Taiwan can reflect the policies and ideologies established by a regime to determine steps of the government. Guy's research intended to examine the objectives, the mechanisms, and the consequences of the state in controlling the arts life.

The investigation on cultural hegemony can also be found in a study entitled "Imaging Culture: Art and Nationalism in Ghana" (Hess, 2000). This study mentioned that the arts serve as a tool to build a national culture. In addition, art is able to guarantee the association between state authority, art, and even constitution. It indicates that art becomes the embodiment of nationalism struggle.

It can be assumed that the state intervention on art is a form of cultural hegemony, in which it contains the purpose to perpetuate the state power. The formulation of the reserach question in this study are, why is the shadow puppet performances managed as the instrument of state hegemony? Starting from this question, the assumptions of answers will be put forward as follow (1) the state and hegemony, (2) the role of traditional puppeters/ intellectual, and (3) the shadow puppet performances as a social expression.

\section{State and Hegemony}

The New Order state was regarded as a powerful state (Giddens, 1987) who could always determine the direction of shadow puppet performances, and as its participation to interfere its performance in order to build the basis of state power through traditional art. If this paper can be developed further, it can be revealed how the New Order state instilled its power politics through traditional art (Soedarsono, 1987).

After the puppeter knew the phenomenon of hegemony, of course, the puppeter who accept and realize the hegemony of New Order can be seen as a form of dictation. New Order era is an authoritarian-bureaucratic state which was supported by military force (Masso, 2002). A strong state will be easy to determine the steps of hegemony.

Gramci also mentions that hegemony is a chain of interests acquired through consensus mechanisms rather than through suppression of other social classes. There are various ways, for example, through existing institutions in society that directly or indirectly determine the cognitive structures of society. It means that hegemony is basically an attempt to lead people to assess and to view social problems within a determined framework.

Gramsci also sees the fact that in society there is always a ruling and ruled group. The concern on the ruling party is to create obedience and to eliminate resistance from the group being ruled. To bring it into reality, according to Gramsci, the ruling class uses the means of domination or oppression in the form of power and hegemony to control on intellectually and morally leadership that can be accepted through consciousness process (Billah, 1996).

\section{The Role of Puppeteer as Traditional Intellectual}

Gramci attempted to analyze the way in which a political rule and hegemony of a class in a historical block were actually actualized, and concretely organized, i.e. examining the problem of intellectual roles as part of its goal of understanding the real unity of the superstructure base. In this case, Gramci divides the schematization of intellectual roles into two divisions: (1) organic intellectuals, and (2) traditional intellectuals (Patria, 2003).

In this case, the traditional intellectual is the one who is in charge of intellectual leadership in a society. The characteristics of traditional intellectual is like the image of continuous historical connection toward the qualifications of esprit de corps. It means that they perceive themselves as autonomous and independent social groups. This view contains consequences in ideological and political fields.

Traditional intellectuals in society are presented with literati, philosophers, and artists. In this case, the puppeteer can be categorized as traditional intellectuals. As an artist, the puppeteer is literati and, at once, performs as philosopher. As traditional intellectuals, the puppeteer is also part of the ruling social group.

The puppeteers and the state in this study viewed as a form of affiliation. This affiliation makes the puppeter hegemonized by the state. The puppeteer position is still used as a guide from intellectual concept (traditional intellectual) which is from civil society and state (Dahana, 2001).

The traditional intellectual can be categorized as an autonomous intellectual, and this category emerges as a representative of a historical continuity which is not affected by radical and complicated changes in social and political form. The form of shadow puppet performances from the past until now, or the performances from the puppeter on each stage are the continuity that remains the same although the country experienced social and political changes. The puppeteer changes in a traditional intellect can be clearly seen, such as when he got a dictation from other, in this case is from the government. As traditional intellectuals, puppeteers are nurtured to convey messages as part of campaign. A puppeteer can make wayang as the best reflection og Javanese life, and 
also describes the relationship between the king and his people in an ideal manner (Moertono, 1985). Moreover, the puppeter also at the same time provides entertainment for the community. The Javanese is very enthusiastic with traditional arts, if there is an art performance takes, the mass will get there.

\section{Shadow Puppet Performance as Social Expression}

The most important aspect of Gramci's theory about intellectual and political party relationships is on his description that the particular role of political parties to articulate the hegemony of the working-class movement. The most important instrument for disseminating the culture of the proletariat is the party, which integrates intellectual collectively. According to Gramci, the party must consist of three elements, namely: (1) popular folklore, (2) leadership, and (3) mediating elements (Patria, 2003).

The structure of Golkar party reflected those three points, such as the democracy foundation, the adequate intellectual actors (the leaders and the candidates), and the longest mediating role for various political, social, and cultural conflicts in Indonesia. It means the democracy base of Golkar should be increasing not decreasing. Therefore, the utilization of accepted and admired art is needed to expand the number of public support for Golkar, i.e. one of them was through puppet art because it is very close to the public community. Thus, the use of puput art performance for the campaign agenda is very appropriate.

The puppet art has long been used to build political communication (Stamatove, 2002). It functioned, at first, to raise the spirit of struggle in the colonial period (Sutiyono, 1991) changed into a campaign medium of President Suharto's political party. The puppet art is a form of social expression because it can build some political movement to address the audience (Stamatove, 2002). As a kind of theataer performance, it contains a stimulus to react in front of the audience. In case of social expression, this art is very potential to arouse the spirit for the wider community (Fisher, 1999). Thus, this art can be an adequate instrument to build the state hegemony. While the socialization process took place, the social expression of the puppet art instilled the attitude and the orientation of political life in the society (Dawson, 1968). Then, they are able to react the promises and policies that have been outlined by the state's political parties through puppet art media. By doing so, the state party can fulfill various agendas as well as accommodate the public interests widely (Powel, 1966).

As a social expression that can be cultivated into the hegemonic building instrument, puppet art is a very powerful vehicle to spread out the values or ideas of political parties and development. Its role and function is crucial since the puppet art is the actualization of the life concepts that teach about mentality and morality. The perceived puppet performance can change the one's mindset into the development of mental attitude which is needed to support the country building (Habib, 2018).

Indeed, the puppet art is not solely for the campaign agendas of the state political party, but its performance can contribute as sustainable support for the development programs of the state mission. It was proved from the various repertoionres of puppet art performances during the era of President Soeharto, which was not only closed to campaign figures such as Pandawa Ringin, Ringin Kembar, Waringin Kencana, and Semar Mbangun Kencana Building, but also the several plays that contained messages of development through gara-gara (comedy) scenes. This part often presented dialogue around greening, clieness, five efforts of farming (panca usaha tani), law awareness, public order and security, Pancasila, village modernization, and so forth. Yet, actually, those programs implied the legitimacy of President Suharto's power, which the public were not aware. The people seemed to enjoy the performance and, at the same time, they were designed to obey to the state programs which was expressed through the puppetry art show.

\section{Conclusion}

The state hegemony on the puppet art is in line with Gramsci's theory (1976) that defined hegemony as political concepts and consequences on the tasks of political parties. In this case, the political party must be able to manage the hegemonic instruments to manage the public to be obedient and controlled by the political party. The strategies taken by the political as well as the state party (Golkar party) was using the puppet art as a medium of social expression and interaction between the state and the public. Before the medium can be considered effective and adequate, the instrument (puppet art) must be hegemonized first, or the puppeteer and the show must be controlled, so that all messages and state dictate on the art of puppet can really be a golden horse (the best and effective vehicle for political expression).

The puppet art should be managed as carefully as possible since the socialization and expression with this art did not only take place during the campaign period, but also after the campaign was done and the state party had become the winner in the general election. In fact, puppet art was effectively used as a means of hegemony because it contains the characteristic and the meaning in the socio-cultural context among the society (Camus, 
1998). With hegemony of puppet art, the state also reach the legitimacy power from the society (Budiman, 1997). This statement suggests that with the expression of art as a hegemonic tool, the state expects the support, sympathy, and adherence of the wider community to yield and to obey the state authority.

The practice of cultural domination that has been mentioned can be seen as an application of Marxist hegemony concept (as Gramsci theory). Marxism states that the culture that exists in a certain era is a culture belonging to the ruling class. Referring to Marxist thought, puppet art in this study consider as the art under the ruling class control at that time, namely the New Order government. As the evidence, most of the puppeteers joined the organization of Pepadi (Association of Indonesian Puppeter), as mentioned earlier.

\section{References}

Billah, M. M. (1996). Good Gorvenance dan Kontrol Sosial Realitas dan Prospek. Prisma, 8, 43.

Brett-Smith, S. C. (2002). Bahama Identity, State Formation, and the Sources of Bahama art. American Anthropologist, 934-944.

Dahana, R. P. (2001). Ideologi Politik dan Teater Modern Indonesia. Magelang: Indonesiatera.

Dawson, R. E., \& Prewitt, K. (1968). Political socialization. Boston: Little, Brown and Co.

Fatah, E. S. (1994). Teori Negara dan Negara Orde Baru: Penjajakan melalui Poulatzas dan Evans. Prisma, 12, 85-103.

Fisher, M. (1999). A Scottish Theatre is not such a Bad Idea. New Statesaman, 20, 96-97.

Giddens, A., \& Held, D. (Eds.). (1987). Perdebatan Klasik dan Kontemporer mengenai Kelompok, Kekuasaan dan Konflik. Terjemahan. Jakarta: Rajawali Press.

Guy, N. A. (1997). Peking Opera and Politics in Post-1949 Taiwan (Ph.D. dissertation). University of Pittsburgh, USA.

Habib, M, H. (2018). Culture and Consumerism in Jean Baudrillard: Postmodern Perspective. Asian Social Science, 14(9), 43-46. https://doi.org/10.5539/ass.v14n9p43

Hess, J. B. (2000). Imaging Culture: Art and Nationalism in Ghana (Ph.D. dissertation). Harvard University.

Masso, I. (2002). Why I Hate Our Official Art? New statesman, January, pp. 11-12. https://www.newstatesman.com/node/194309.

Moertono, S. (1985). Negara dan Usaha Bina-Negara di Jawa Masa Lampau: Studi tentang Masa Mataram II Abad XVI sampai XIX. Jakarta: Yayasan Obor Indonesia.

Nugroho, S. (2003). Pertunjukan wayang Gedhog Dengan Berbagai Permasalahannya. SENI, Jurnal Pengetahuan dan Penciptaan Seni, IX/02-03, Maret, 79-86.

Patria, N., \& Arief, A. (2003). Antonio Gramsci Negara dan Hegemoni. Yogyakarta: Pustaka Pelajar.

Powel, G. B. (1966). Comparative Politics Developmental Approach. Boston: Little, Brown and Co.

Soedarsono. (1987). Wayang Wong: The State Ritual in the Court of Yogyakarta. Yogyakarta: Gadjah Mada University Press.

Sperling, J. (2001). Neither Hegemony Nor Dominance: Reconsidering German Power in Post Cold-war Europe. British journal of Political Science, March, 389-425. https://doi.org/10.1017/S0007123401000151

Stamatov, P. (2002). Interpretative Activism and The Political Uses of Verdi's Opera in The 1840s. American Sociological Review, 345-366. https://doi.org/10.2307/3088961

Sutiyono. (1991). Seni Pewayangan dalam Perubahan Kebudayaan. Cakrawala Pendidikan, 10(3), 107. IKIP Yogyakarta.

\section{Copyrights}

Copyright for this article is retained by the author(s), with first publication rights granted to the journal.

This is an open-access article distributed under the terms and conditions of the Creative Commons Attribution license (http://creativecommons.org/licenses/by/4.0/). 